\title{
Efektifitas Dosis Biofungisida Pelet Trichodermasp.Untuk Mencegah Perkembangan Jamur Ganoderma boninense Pada Pembibitan Kelapa Sawit
}

\author{
Effectivity Doses of Pellet biofungicides Trichoderma sp.To Prevent Fungal Development of \\ Genoderma boninense In Oil Palm Nusreries
}

\author{
Ikhsan $^{1}$, Hartati Oktarina ${ }^{2}$, Tjut Chamzurni \\ ${ }^{1}$ Jurusan Agrotenologi, Fakultas Pertanian, Universitas Syiah Kuala \\ ${ }^{2}$ Jurusan Proteksi Tanaman, Fakultas Pertanian, Universitas Syiah Kuala \\ *Corresponding author:tjut_cham @unsyiah.ac.id
}

\begin{abstract}
Abstrak. Ganoderma boninense adalah jamur patogen yang mengakibatkan tanaman yang belum menghasilkan dan tanaman menghasilkan pada kelapa sawit menjadi layu dan mati. Alternatif pengendalian yang dapat dilakukan untuk mencegah penyakit busuk pangkal batang (BPB) yang disebabkan jamur G.boninense pada bibit kelapa sawit adalah pengendalian biologis biofungisida pelet yang mengandung spesies Trichoderma harzianum dan Trichoderma virens. Faktor yang menentukan berhasilnya bioungisida pelet adalah dosis yang digunakan. Penelitian ini bertujuan untuk mengetahui dosis efektif biofungisida pelet untuk mencegah penyakit BPB. Penelitian ini dilakukan dengan menggunakan Rancangan Acak Lengkap Non Faktorial yang terdiri dari 7 perlakuan dan 3 ulangan. Tiap unit terdiri dai 4 bibit yang masing-masing ditanam pada $1 \mathrm{~kg} /$ polibag. Perlakuannya menggunakan dosis biofungisida pelet spesies $T$. harzianum dan $T$. Virens yaitu $0,1.5,2.5$ dan $3.5 \mathrm{~g} /$ polybag. Data pengamatan yang diperoleh dari hasil analisis sidik ragam akan dilakukan uji lanjut Beda nyata terkecil (BNT) apabila perlakuan berbeda nyata. Hasil penelitian dari uji beberapa dosis biofungisida pelet spesies $T$. harzianum dan $T$. virens padamasa inkubasi dan Persentase tanaman terserang menunjukkan pengaruh sangat nyata dalam mencegah jamur G. boninense. Pada jumlah daun 120 HSI juga menunjukkan pengaruh nyata terhadap beberapa dosis biofungisida pelet Trichoderma dan pengaruh faktor usia dari kelapa sawit.
\end{abstract}

Kata Kunci : G.boninense, Bibit Kelapa Sawit, T. harzianum, T. Virensdan dosis biofungisida pelet

Abstract. Ganoderma boninense is pathogenic fungi that attacks immature plants and plants producing oil palm be withered and died. Alternative control that can be done to prevent basal stem rot disease (BPB) which is caused by $G$. boninense on oil palm seeds is biological control of pellet biofungicides including $T$. harzianum and $T$. Virens species. The factor that determines the success of pellet biofungicide is the dose used. This study aims to determine the effective dosage of pellet biofungicides to prevent BPB. This research was using a Non Factorial Completely Randomized Design consisting of 7 treatments and 3 replications. The treatment used doses of pellet biofungicide of T. harzianum and T. Virens species which are $0,1.5,2.5$ and $3.5 \mathrm{~g}$ / polybag. Observation data was obtained from the results of the using variance that will be carried out by the least significant differences (LSD) if the treatment is significantly different. The study results of several doses of pellet biofungicide $T$. harzianum and $T$. Virens species during the incubation period and the percentage of attacked plants showed a very significant influence in preventing G.boninense fungi. The number of leaves 120 HSI also showed a significant effect on several doses of Trichoderma pellet biofungicide and the influence of age factors from oil palm.

Keywords : G. boninense. Young Palm Oil, T. harzianum, T. Virensand granular biofungicide dosages

\section{PENDAHULUAN}

\section{Latar Belakang}

Kelapa sawit (Elaeis guineensis Jacq.) adalah salah satu dari jenis tanaman perkebunan yang sangat penting dalam sektor perkebunan dan pertanian pada umumnya, 
karena hasil utamanya Crude palm oil dan turunannya menjadi komoditas pedagangan yang besar bagi Indonesua dan penyumbang devisa terbesar dalam sektor perkebunan. (Khaswarina, 2001).

Sejalan dengan perluasan daerah perkebunan di wilayah Aceh, luas lahan dan produktivitas kelapa sawit di Aceh dalam tiga tahun terakhir meningkat. Luas perkebunan kelapa sawit pada tahun 2015 seluas 3.224 ha dengan jumlah produksi 1.799 ton. Pada tahun 2016 seluas 228.230 ha dengan hasil produksinya yaitu 399.618 ton dan pada tahun 2017 seluas 321.903 ha dengan produksi 1.077.099 ton. (Badan Pusat Statistik Aceh, 2017).

Pertumbuhan kelapa sawit tidak terlepas dari serangan patogen. Salah satunya patogen yang menyerang kelapa sawityaitu Ganoderma boninense,yang menyebabkan penyakit Busuk Pangkal Batang (BPB)(Semangun, 2000).Kementerian Pertanian (2012) melaporkan bahwa enam provinsi di Indonesia telah teridentifikasi adanya penyakit busuk pangkal batang yang disebabkan oleh G. boninense. Enam provinsi tersebut adalah Aceh, Riau, Sumatera Barat, Kalimantan Tengah, Bengkulu dan Sumatera Utara. Total luas lahan kelapa sawit yang terserang sekitar 2.428,33 ha dengan nilai kerugian mencapai Rp. 3,6 miliar. Penyakit BPB saat ini juga mulai menyerang tanaman generasi pertama pada daerah pengembangan baru kelapa sawit di Sulawesi dan Papua.

Trichoderma sp.mengendalikan patogen dengan dua cara yaitu secara langsung dan secara tidak langsung. Secara langsung ialah dengan menjadi jamur parasit bagi patogen. Sebagai contoh pertumbuhan T. harzianum sebagai cendawan parasitpada Rhizoctonia solani dengan cara melilit dan selanjutnya masuk serta tumbuh di dalam hifa $R$. solani, dan menyebabkan hifa pecah (Aslamiyah, 2003). Secara tidak langsung T. harzianum bertindak sebagai kompetitor dalam memperebutkan nutrisi, oksigen dan ruang dan juga mampu bertahan hidup dalam waktu yang lama tanpa ada inangnya. (Benitez et al., 2004).

Pemberian dalam bentuk substrat ini kurang praktis dan efisien terutama untuk tujuan aplikasi dalam skala luas di lapangan sehingga perlu dikembangkan suatu teknik pengemasan dalam suatu bentuk formulasi biofungisida. Agens hayati telah banyak diformulasikan dalam bentuk tepung, cair, butiran dan pelet. Formulasi berbentuk pelet memiliki struktur semi padat yang memungkinkan bahan aktif tidak mudah rusak oleh sinar matahari atau air hujan. Selain itu formulasi pelet berukuran lebih kecil sehingga mudah dalam pengangkutan, penyimpanan dan aplikasi lapangan. Formulasi biofungisida pelet terdiri atas bahan aktif T. harzianum, bahan makanan, bahan pembawa dan bahan pencampur (Purwantisari et al., 2008).Hasil penelitian Zikriah (2016) juga menyatakan bahwa T. harzianum dengan formulasi pelet berbahan dasar DDK (Dedak dan Daun Katuk) mempunyai daya hambat paling tinggi terhadap pertumbuhan koloni Sclerotium spp. maupun Rhizoctonia spp. dibandingkan dengan formulasi yang lain, yaitu masing-masing 75,0\% terhadap Sclerotium spp., dan 68,9\% terhadap Rhizoctonia spp. Penelitian terhadap daya hambat Trichoderma sp. dalam berbagai dosis dengan formulasikering berbentuk tablet juga telah dilakukan.

Selain formulasi, faktor yang menentukan keberhasilan biofungisida adalah dosis yang digunakan. Biofungisida pelet $T$. harzianum dengan dosis $10 \mathrm{~g} /$ polybag memiliki kemampuan yang lebih baik dalam mengendalikan jamur $G$. boninense dan meningkatkan pertumbuhan bibit kelapa sawit. (Elfina et al., 2015; Harmidi dan Susanto, 2000).

Dalam penelitian ini, beberapa dosis pelet T. harzianum danT. Virens berbahan dasar dedak dan daun katuk diaplikasikan pada bibit kelapa sawit untuk mencegah penyakit BPB yang disebabkan oleh $G$. boninense. 


\section{Hipotesis}

$\mathrm{H}_{0}$ : Cendawan $T$. harzianum danT. Virenspada dosis tertentu tidak dapat mencegah perkembangan penyakit BPB pada tanaman kelapa sawit (E. guineensis)di pembibitan.

$\mathrm{H}_{1}$ : Cendawan $T$. harzianum danT. Virenspada dosis tertentu dapat mencegah perkembangan penyakit BPB pada tanaman kelapa sawit (E. guineensis)di pembibitan.

\section{METODE PENELITIAN}

Penelitian dikerjakan dari bulan September 2018 sampai Januari 2019, di Laboratorium Ilmu Penyakit Tumbuhan dan di Kebun Percobaan Fakultas Pertanian, Universitas Syiah Kuala, Banda Aceh.

\section{MATERI DAN METODE}

Alat yang dipakai adalah cawan petri, gelas ukur, tabung reaksi, beaker glass, shaker, erlenmeyer, laminar air flow, sprayer, aquades, jarum ose, mikroskop,pisau scapel, autoklaf, timbangan analitik,tempa adonan, pipet ukur, lampu bunsen, inkubator, Brass cookie maker, gunting, mistar dan alat dokumentasi. Bahan yang dipakai adalahbibit kelapa sawit berumur 1 bulan yang berasal di Desa Seuot Baroh Kecamatan Indrapuri Kab Aceh Besar, biakan G. boninense, isolat T.harzianum dan T.virens koleksi Laboratorium Penyakit Tumbuhan Unsyiah, bahan dasar pelet (dedak, daun katuk),molase, akar kelapa sawit yang sudah dipotong $1 \mathrm{~cm}$, alkohol 70\%, aluminium foil, plastik polyethilene, plastik zip, sungkup plasik, kapas, Potato Dextrose Agar (PDA), aquades dan polibag volume $1 \mathrm{~kg}$ dan pupuk kandang.

\section{Metode Penelitian}

Penelitian ini menggunakan rancangan acak lengkap (RAL) pola non faktorial dengan 7 perlakuan dan 3 ulangan. Setiap ulangan terdiri dari 4 unit Sehingga terdapat 84 unit percobaan. Perlakuan -perlakuan tersebut disajikan pada Tabel 1.

Tabel 1. Susunan perlakuan dosis peletT. harzianum danT. Virens untuk mencegah jamur G.boninense

\begin{tabular}{c|c}
\hline Perlakuan & Dosis Pelet(gram/polybag) \\
\hline K (Kontrol) & $\mathbf{0}$ \\
\hline TH1 (T.harzianum) & $\mathbf{1 , 5}$ \\
\hline TH2 (T.harzianum) & $\mathbf{2 , 5}$ \\
\hline TH3 (T.harzianum) & $\mathbf{3 , 5}$ \\
\hline TV1 (T.virens) & $\mathbf{1 , 5}$ \\
\hline TV2 (T.virens) & $\mathbf{2 , 5}$ \\
\hline TV3 (T.virens) & $\mathbf{3 , 5}$ \\
\hline
\end{tabular}

Setelah data didapatkanya, selanjutnya dianalisis secara statistik dengan ANOVA (analysis of variance) untuk melihat pengaruh perlakuan. Bila perlakuan berpengaruh nyata, maka dilakukan analisis lanjut menggunakan uji BNT pada taraf 5\%.

\section{Prosedur Pengujian di Laboratorium}

Penelitian ini terdiri atas dua tahap yaitu pelaksanaan di laboratorium dan di lahan penelitian kebun percobaan Fakultas Pertanian Universitas Syiah Kuala. Peremajaan isolat jamur T. harzianum, T. Virens dan G. boninense dilakukan dengan cara direisolasi dengan 
memindahkan miselium yang tumbuh dalam media PDA dengan menggunakan jarum ose steril ke dalam cawan petri lain dan diinkubasi dalam inkubator selama 7 hari. Biofungisida pelet Trichoderma terdiri dari bahan aktif (T. harzianum dan T. Virens). Semua bahan seperti daun katuk, dedak (DDK) dan tambahan molase diaduk hingga homogen dan dimamsukkan dalam plastik polyethylene kemudian di autoklaf $121{ }^{\circ} \mathrm{C}$ selama 30 menit. Setelah itu $T$. harzianum dan $T$. Virens diberi $1 \mathrm{ml}$ suspensi dan dimasukkan kedalam bahan adonan DDK dan diinkubasi selama 30oC selama 48 jam hingga kering, kemudian dipotong dengan ukuran $3 \mathrm{~cm}$ dan dimmasukkan dalam plastik zip. Bibit kelapa sawit merupakan varietas dxp Simalungun berumur 1 bulan, medianya yaitu tanah top soil dengan perbandingan $2: 1$ dengan pupuk kandang.

Pelet T. harzianum dan T. Virens diaplikasikan pada bibit kelapa sawit pada 8 hari sebelum diaplikasikannya jamur $G$. boninense. Jamur $G$. boninense. diinokulasi pada 8 hari setelah diaplikasikanya pelet. Cara pengaplikasiannya dibuat lubang disekitar perakaran dengan kedalaman $5 \mathrm{~cm}$ kemudian dibenamkan pelet $T$. harzianum dan $T$. Virens dan $G$. boninense dilukai akar primer dulu dan diletakkan 2 akar kelapa sawit yang diinokulasi $G$. boninense. Penyiraman dilakukan dengan menggunakan sprayer setiap pagi dan sore hari.

\section{Parameter Pengamatan}

Adapun indikator yang diamati adalah masa inkubasi, tinggi bibit kelapa sawit yang diukur dari pangkal batang sampai ujung daun tertinggi , Jumlah pelepah daun yang dihitung dari bagian daun terbawah sampai daun termuda yang telah membuka sempurna interval waktu dihitung dari 0, 30, 60, 90, 120 hari setelah inokulasi (HSI).

Pengamatan persentase tanaman terserang diamati pada akhir penelitian dengan menggunakan rumus : $\mathrm{p}=\frac{a}{b} \times 100 \%$

Keterangan :

$\mathrm{P}=$ persentasetanaman terserang

$\mathrm{a}=$ Jumlah tanaman terserang

$\mathrm{b}=$ Jumlah tanaman yang diamati

\section{HASIL DAN PEMBAHASAN}

\section{Hasil Penelitian}

\section{Masa Inkubasi Setelah Inokulasi Patogen}

Hasil penelitian menunjukkan bahwa, rata-rata masa inkubasi tercepat dijumpai pada perlakuan kontrol yaitu tanpa biofungisida pelet T. harzianum dan T. Virens 102 HSI. Masa inkubasi pada perlakuan biofungisida pelet 3,5 g/polibag (TV3) dan 3,5 g/polibag (TH3) cenderung lebih lambat dari perlakuan $0 \mathrm{~g} /$ polibag (kontrol) yaitu 109,37, dan 111,37 HSI. Pada perlakuan 1,5 g/polibag (TH1) dan 1,5 g/polibag (TV1) menunjukkan gejala awal lebih lama dibandingkan perlakuan lainnya yaitu 119,50 hari, 119,16 HSI. Pada perlakuan 2,5 $\mathrm{g} /$ polibagTH2) dan 2,5 g/polibag (TV2) selama dilaksanakan penelitian tidak ditemukannya gejala pada perlakuan tersebut.

Tabel 2. Rata-rata Masa Inkubasi (hari) Patogen G. boninense pada pembibitan kelapa sawit.

*Corresponding author:tjut_cham @unsyiah.ac.id 
Masa inkubasi (hari)

$0 \mathrm{~g} /$ polybag (kontrol) $\quad 102,00$

$1,5 \mathrm{~g} /$ polibag $(\mathrm{TH} 1)$

119,50

2,5 g/polibag (TH2)

Tidak ada gejala

3,5 g/polibag (TH3)

111,37

$1,5 \mathrm{~g} /$ polibag (TV1)

119,16

2,5 g/polibag (TV2)

Tidak ada gejala

$3,5 \mathrm{~g} /$ polibag (TV3)

109,37

Rerata

112,28

\section{Tinggi bibit tanaman (cm)}

Hasil uji $\mathrm{F}$ menunjukkan bahwa rata-rata tinggi bibit kelapa sawit akibat perlakuan dosis pelet $T$. harzianum danT. Virens menunjukkan hasil yang paling rendah pada perlakuan 120 HSI yaitu perlakuan (kontrol) $59,42 \mathrm{~cm}$. Pada dosis pelet $T$. harzianum yang rendah tinggi tanamannya yaitu perlakuan 1,5 g/polibag (TH1) 63,10 cm dan yang paling tinggi yaitu pada perlakuan $2,5 \mathrm{~g} /$ polibag (TH2) 70,85. Pada dosis pelet $T$. Virensyang rendah tinggi tanamannya yaitu perlakuan $1,5 \mathrm{~g} /$ polibag (TV1) $67,21 \mathrm{~cm}$ dan yang paling tinggi yaitu pada perlakuan 2,5 g/polibag (TV2) 69,78.

Tabel 3. Rata-Rata Tinggi Tanaman Kelapa Sawit pada 0, 30, 60, 90 dan 120 HSI akibat Perlakuan Dosis pelet $T$. harzianum dan T. Virensdalam mencegah Jamur $G$. boninense.

\begin{tabular}{lccccc}
\hline \multirow{2}{*}{ Perlakuan } & \multicolumn{5}{c}{ Hari ke - } \\
\cline { 2 - 6 } & 0 & 30 & 60 & 90 & 120 \\
\hline 0 g/polibag (kontrol) & 48,92 & 50,64 & 55,11 & 57,73 & 59,42 \\
1,5 g/polibag (TH1) & 47,82 & 48,58 & 54,92 & 59,33 & 63,10 \\
2,5 g/polibag (TH2) & 49,36 & 52,29 & 61,13 & 68,39 & 70,85 \\
3,5 g/polibag (TH3) & 46,29 & 49,88 & 55,43 & 58,99 & 64,50 \\
1,5 g/polibag (TV1) & 50,24 & 51,70 & 57,23 & 62,92 & 67,21 \\
2,5 g/polibag (TV2) & 50,70 & 53,10 & 58,97 & 64,88 & 69,78 \\
3,5 g/polibag (TV3) & 51,41 & 53,35 & 60,50 & 66,14 & 69,15 \\
\hline
\end{tabular}

Keterangan : Angka-angka yang diikuti oleh huruf yang sama pada kolom yang sama berbeda tidak nyata berdasarkan uji BNT pada taraf 5\%.

\section{Jumlah Daun (helai)}

Hasil uji $\mathrm{F}$ menunjukkan bahwa rata-rata jumlah daun bibit kelapa sawit pada perlakuan dosis yang berbeda akibat pemberian biofungisida pelet 0, 30, 60dan 90 HSI berpengaruh tidak nyata dan pada 120 HSI bibit tanaman kelapa sawit berpengaruh sangat nyata terhadap pertumbuhan jumlah daun bibit kelapa sawit.

Tabel 4. Rata-Rata jumlah daun Tanaman Kelapa Sawit pada 0, 30, 60, 90 dan 120 HSI akibat Perlakuan Dosis pelet T. harzianum dan T. Virensdalam mencegah Jamur $G$. boninense.

\begin{tabular}{rccccc}
\hline \multirow{2}{*}{ Perlakuan } & \multicolumn{6}{c}{ Hari ke } \\
\cline { 2 - 6 } & 0 & 30 & 60 & 90 & 120 \\
\hline 0 g/polibag (kontrol) & 7,42 & 7,67 & 8,00 & 8,67 & $8,75 \mathrm{ab}$
\end{tabular}

*Corresponding author:tjut_cham @unsyiah.ac.id 


\begin{tabular}{cccccc}
\hline \hline & & & & & \\
1,5 g/polibag (TH1) & 7,25 & 7,42 & 8,33 & 8,75 & $8,77 \mathrm{ab}$ \\
2,5 g/polibag (TH2) & 7,00 & 7,25 & 8,50 & 8,75 & $9,25 \mathrm{bc}$ \\
3,5 g/polibag (TH3) & 6,92 & 7,17 & 8,08 & 8,33 & $8,42 \mathrm{a}$ \\
1,5 g/polibag (TV1) & 7,25 & 7,33 & 8,25 & 8,67 & $9,08 \mathrm{bc}$ \\
2,5 g/polibag (TV2) & 6,83 & 7,17 & 8,42 & 8,83 & $9,58 \mathrm{c}$ \\
3,5 g/polibag (TV3) & 7,42 & 7,58 & 8,50 & 9,33 & $9,50 \mathrm{c}$ \\
\hline BNT 0,05 & tn & tn & tn & tn & 0,52 \\
\hline
\end{tabular}

Keterangan : Angka-angka yang diikuti oleh huruf yang sama pada kolom yang sama berbeda sangat nyata berdasarkan uji BNT taraf 5\%.

\section{Persentase Tanaman Terserang}

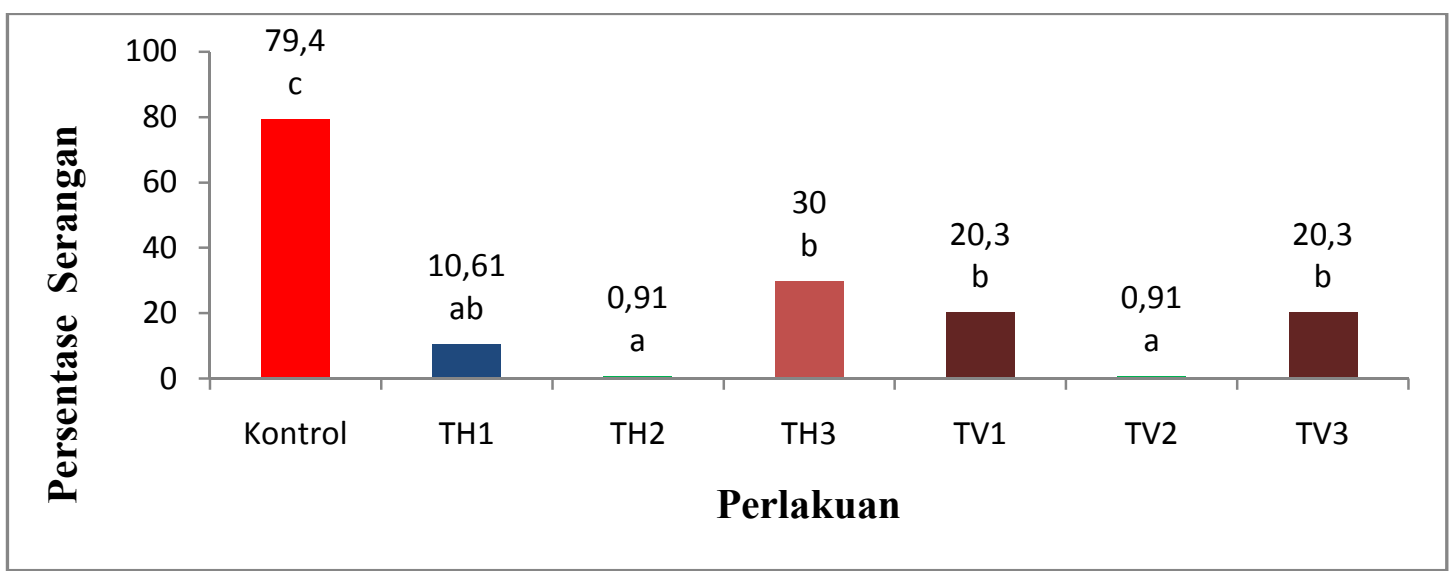

Gambar 1. Rata-rata Persentase Serangan (\%) Patogen G.boninense pada Tanaman Kelapa Sawit Akibat Perlakuan Dosis Biofungisida Pelet T.harzianum dan T.virens. Angka-angka yang diikuti oleh huruf yang sama Berbeda sangat nyata pada taraf Uji BNT 5\%. Data ditransfomasi Arcsin $\sqrt{\mathrm{X}}$. A $=6$ olybag, TH1 = 1,5 g/6olybag, TH2 = 2,5 g/6olybag, TH3 = 3,5 g/6olybag, TV1 = 1,5 g/6olybag, TV2 = 2,5 $\mathrm{g} / 6$ olybag, TV3 $=3,5 \mathrm{~g} /$ polybag.

Dari hasil gambar diatas menunjukkan bahwa perlakuan (6olybag) berbeda sangat nyata dengan perlakuan lainnya, dapat dilihat bahwa persentase bibit kelapa sawit yang terserang penyakit paling tinggi terdapat pada perlakuan (6olybag) $0 \mathrm{~g} / 6 \mathrm{olybag}$ (6olybag) yaitu 91,67\%. Perlakuan 1,5 g/6olybag (TH1) $10,61 \%$, perlakuan 3,5 g/6olybag (TH3) 30\%, perlakuan 1,5 g/6olybag (TV1) dan 3,5 g/6olybag (TV3) 20,3\%, Pada perlakuan 2,5 g/6olybag (TH2) dan 2,5 g/6olybag (TV2) dari kedua spesies Trichoderma selama penelitian tidak dijumpai adanya gejala awal penyakit BPB.

\section{Pembahasan}

\section{Masa Inkubasi Setelah Inokulasi Patogen}

Masa inkubasi pada perlakuan $0 \mathrm{~g} /$ polybag, 1,5 g/polybag dan 3,5 g/polybag dari kedua jenis Trichodermakurang efektif dalam menghambat perkembangan jamur $G$. boninensekarena menimbulkan persaingan antar populasi cendawan antagonis dalam mencukupi kebutuhan makanan dan ruang yang tidak begitu tinggi. Hal ini menurut 
Simanungkalit et al., (2006) dosis yang berlebihan pada tanaman akan menyebabkan persaingan antar mikroba terjadi dalam memperoleh makanan dan berpengaruh terhadap kebutuhan nutrisi mikroba.

Pada perlakuan biofungisida pelet 2,5 g/polibag (TH2) dan dan 2,5 g/polibag (TV2) tidak menunjukkan gejala awal selama penelitian. Troian et al., (2014) menambahkan bahwa Trichodermasp memliki kemampuan dalam mengendalikan patogen penyebab penyakit tanaman dengan mensekresi enzim hidrolitik dan juga memiliki kemampuan beradaptasi dengan cepat pada lingkungan yang tidak menguntungkan.

\section{Tinggi bibit tanaman (cm)}

Tinggi tanaman pada kelapa sawit akibat perlakuan dosis biofungisida pelet $T$. harzianum dan $T$. Virensdengan dosis berbeda tidak berpengaruh nyata terhadap tinggi bibit. Hal ini diduga karena tinggi bibit yang tidak diberi biofungisida pelet hanya mendapatkan unsur hara yang ada pada medium tanam serta memiliki intensitas penyakit yang tinggi. Ini didukung dengan pendapat Kurniawan et al.,(2005) bahwa patogenitas yang tinggi pada suatu tanaman menyebabkan tanggap tanaman lebih rentan, sehingga tanaman terserang hebat dan juga berpengaruh pada pertumbuhan tanaman.

Pemberian biofungisida pelet perlakuan 2,5 g/polibag (TH2) dan (TV2) cenderung menunjukkan bibit yang lebih tinggi. Cleland (1972) menyebutkan bahwa beberapa spesies Trichodermaseperti T. harzianum danT. Virensmenghasilkan indol-3-acetid acid (IAA).

\section{Jumlah Daun (helai)}

Hal ini diduga karena perbedaan perlakuan 0, 30, 60 dan 90 HSI tidak berperan pada pertumbuhan daun bibit kelapa sawit, ini dapat disebabkan pada fase umur tertentu dapat meningkatkan jumlah daunnya. Pada perlakuan 120 HSI jumlah daun berpengaruh sangat nyata kondisi ini diduga dipengaruhi oleh interaksi antara umur bibit dengan hormon pemacu pertumbuhan yang ada pada jamur antagonis.Menurut Azamri et al., (2011) menyatakan bahwa pemberian Trichoderma sp. dapat meningkatkan jumlah daun, serta mampu meningkatkan kadar klorofil pada daun, sejalan dengan pendapat Roco dan Perez (2001) menyatakan bahwa $T$. harzianum mampu menghasilkan asam giberelin, benzyl amino purin (BAP) dan hormon IAA yang dapat menstimulasi petumbuhan.

\section{Persentase Tanaman Terserang}

Tingginya persentase tanaman terserang pada bibit kelapa sawit yang tanpa biofungisida pelet Trichoderma $(0 \mathrm{~g} /$ polybag $)$ karena tidak adanya cendawan spesies Trichodermasp. Abadi (2007) menyatakan bahwa gejala G.boninense terlihat pada daun yang tampak seperti kekurangan air dan unsur hara yang terlihat pada tajuk tanaman daun muda yang terlihat lebih pucat (klorosis).

Pada perlakuan 2,5 g/polibag (TH2) dan 2,5 g/polibag (TV2) dari kedua spesies Trichoderma selama penelitian tidak dijumpai adanya gejala awal serangan patogen yang disebabkan oleh G.boninense. Habazar dan Yaherwandi(2006) T. harzianum dapat menghasilkan enzim kitinase yang dapat menghidrolisis kitin dari dinding sel patogen sehingga menyebabkan lisis. Sejalan dengan Rogis et al. (2007) bahwa kitinase merupakan enzim yang penting untuk mengendalikan jamur patogen karena enzim ini dapa menyebabkan terurainya dinding sel hifa serta perubahan komposisi sitoplasma sel patogen yang menginfeksi tanaman dan merespon resistensi dari tanaman, sehingga dapat menurunkan intensitas serangan penyakit pada tanaman

*Corresponding author:tjut_cham @unsyiah.ac.id 


\section{KESIMPULAN DAN SARAN}

\section{Kesimpulan}

Pemberian dosis biofungisida pelet spesies T. harzianum dan $T$. Virensberpengaruh sangat nyata terhadap masa inkubasi, persentase tanaman terserang patogen $G$. boninense dan pada jumlah daun di pembibitan kelapa sawit di 120 HSI. Pemberian dosis biofungisida pelet T.harzianum dan T.virens dengan dosis $2,5 \mathrm{~g} /$ polybag lebih baik dalammencegah jamur $G$. boninense dibandingkan dengan dosis lainnya.Meningkatnya jumlah daun dipengaruhi dosis biofungisida pelet spesies T.harzianum dan T.virensakibat adanya hormon pemacu pertumbuhan pada cendawan antagonis.oleh umur tanamankelapa sawit.

\section{Saran}

Perlunya dilakukan penelitian lanjutan kombinasi antara spesies Trichoderma sp. dalam berbagai formulasi agar dapat diketahui formulasi yang efektif di lapangan dalam menekan perkembangan jamur G.boninense.

\section{DAFTAR PUSTAKA}

Abadi, A. L. 2007. Biologi Ganoderma boninense Pat. pada kelapa sawit (Elaeis guineensis jacq) dan pengaruh beberapa mikroba tanah antagonistik terhadap pertumbuhannya. Disertasi. Program Pasca Sarjana Institut Pertanian Bogor, Bogor.

Aslamiyah, S. 2003. Optimalisasi dan Keefektifan Agen Biokontrol Trichoderma harzianum dalam Mengendalikan Penyakit Busuk Pangkal Batang Kelapa Sawit Secara In-Vitro. Skripsi. Jurusan Hama dan Penyakit Tumbuhan, Fakultas Pertanian Universitas Syiah Kuala. Darussalam, Banda Aceh.

Azamri, R., G. Hajienghrari dan A. Giglou. 2011. Effect of Trichoderma isolates on tomato seedling growt response and nutrient uptake. African jurnal of biotechnology. $10: 5850$ -5855 .

Badan Pusat Statistik Aceh. 2017. Luas Panen, Produksi dan Produktivitas kelapa sawit 2017 (On-line). http://www.bps.go.id/tab_sub/view.php?tab el=1\& daftar $=1$ \& id_subyek $=55 \&$ notab $=14$, Diakses tanggal : 10 Juli 2018 .

Benitez, T., A. M. Rincon., M. C. Limon., A. C. Condon. 2014. Biocontrol mechanisms of Trichoderma strains. International Microbiology 7 : 249-260.

Cleland, R. 1972. The dosage-response curve for auxininduced cellelongation. Are-Evaluation Planta. 104: 1-9.

Elfina, Y., M. Ali dan Delfina 2015. Penggunaan Biofungisida Pelet Trichoderma harzianum pada Pembibitan Awal Kelapa Sawit. J. Agrotek. Trop. 4 : 30-37.

Habazar, T. dan Yaherwandi. 2006. Pengendalian Hayati Hama dan Penyakit Tumbuhan. Andalas University Press. Padang.

Harmidi, S dan A. Susanto. 2000. Menuju Sukses Pengendalian Ganoderma dengan Biofungisida Marfu. Prosiding Pertemuan Teknis Kelapa Sawit III Tahun 2000. Medan. 3-4 Oktober 2000.

*Corresponding author:tjut_cham @unsyiah.ac.id 
Kementrian Pertanian. 2012. Sawit Indonesia. http://ditjenbun.deptan.go.id/. Diakses tanggal : 28 September 2018.

Khaswarina, S., 2001. Jurnal Natur Indonesia Keragaman Bibit Kelapa Sawit Terhadap Pemberian Berbagai Kombinasi Pupuk di Pembibitan Utama. Fakultas Pertanian Universitas Sumatera Utara.

Kurniawan, A., E. Prabowo., N. Prihatiningsih dan L. Soesanto. 2005. Potensi Trichoderma harzianum dalam Mengendalikan Sembilan Isolat Fusarium oxysporum schlecht. f.sp. zingiberi trujillo pada Kencur. Skripsi. Universitas Jenderal Soedirman. Purwokerto.

Purwantisari, S., A. Priyatmojo dan B. Raharjo. 2008. Produksi Biofungisida Berbahan Baku Mikroba Antagonis Indigonius untuk Mengendaliakan Penyakit Lodoh Tanaman Kentang Di Sentra-Sentra Pertanaman Kentang di Jawa Timur. http:// balitbangjateng.go.id/kegiatan/rud/2008/8-biofungisida.pdf. Diakses tanggal : 19 Januari 2019.

Roco, A. dan L. M. Perez. 2011. Biocontrol activity o Trichoderma harzianum on altenaria arnat in presence of growth regulation. J. Biotech. $4: 1-6$.

Rogis, A. T. Pameskas dan Mucharromah. 2007. Karakteristik dan uji efikasi senyawa bahan alami chitosan terhadap patogen pasca panen antraknosa Collectrotichum musae. J. Ilmu-ilmu pertanian Indonesia. $9:$ 58-63.

Semangun H. 2000. Penyakit-Penyakit Tanaman Perkebunan di Indonesia. Gadjah Mada University Press. Yogyakarta.

Simanungkalit, R. D. M., Didi, A. S., Rasti, S., Diah, S. dan Wiwik, H.2006. Pupuk Organik dan Pupuk Hayati. Balai Besar Penelitian dan Pengembangan Sumberdaya Lahan Pertanian. Jawa Barat.

Troian, R. F., A. S. Steindorff., M. H. Ramada dan C. J. Ulhoa. 2014. Mycoparasitism studies off Trichoderma harzianum against scelortium : evaluation of antagonism and expression of cell wall-degrading enzymes genes. J. Biotechnol. 36 : 2095-2101. 